\title{
PENERAPAN KONSELING KELOMPOK TERHADAP PENURUNAN PERILAKU AGRESIF SISWA SEKOLAH MENENGAH PERTAMA
}

\author{
Oleh: \\ Fifqi Al-Rais, Suroso, Sahat Saragih \\ Universitas 17 Agustus 1945 Surabaya, Indonesia \\ fifqialrais@gmail.com
}

\begin{abstract}
:
Adolescence is a time when someone has negative behavior, a difficult phase for children and parents. Emotional imbalance and instability in many ways manifest itself at this time. Emotional inconsistency in adolescents causes adolescents to act responsively such as aggressive, rebellious, stubborn, annoying behavior, which results in social problems in interacting with those around them. The aggressive behavior of students in schools has become a universal problem, and is likely to increase recently. The purpose of this study was to see the application of group counseling to decrease the aggressive behavior of high school students. Another objective of the study is to examine the differences in the application of group counseling before and after treatment. Purposive sampling and aggressive scales were used in this experiment, to obtain 20 samples consisting of 10 students in the control group and 10 students in the experimental group at SMP Negeri 13 Surabaya who were recorded as having committed aggression at school. The rule used is a quantitative approach to analyzing data. The results of the field survey showed that students often protested and disrespected teachers, cursed, cursed, made chaos, made noise, said indecent words, and lied. By utilizing group dynamics, the authors provide group counseling interventions to reduce students' aggressive behavior. From the results of the study, it is proven that group counseling has an effect on decreasing aggressive behavior of junior high school students.
\end{abstract}

Keywords: Perilaku Agresif Remaja, Konseling Kelompok, Dinamika Kelompok

\section{A. Pendahuluan}

Sekolah dan keluarga adalah dua sistem yang sangat penting dalam kehidupan anak-anak dan remaja. Keluarga berperanan besar dalam mempengaruhi anak-anak dalam proses perkembangan dan 
sosialisasi. Anak-anak belajar corak tingkah laku awal, berkomunikasi, meluahkan perasaan, belajar nilai dan sikap dalam keluarga. Kemudian setelah anak memasuki sekolah, sekolah tidak hanya mengembangkan kemahiran kognitif, tetapi juga mempengaruhi perkembangan tingkah laku emosi dan sosial. Oleh karna itu, anak-anak dipengaruhi oleh keduadua sistem tersebut.

Remaja adalah masa ketika seseorang mempunyai tingkah laku negatif, fasa sukar bagi anak-anak dan orang tua. Ketidakseimbangan dan ketidakstabilan emosi dalam banyak cara wujud dalam tempoh ini ${ }^{1}$. Ketidakselesaan emosi pada remaja menyebabkan banyak remaja bertindak balas secara defensif seperti yang dilihat dalam tingkah laku yang tidak sesuai seperti agresif, memberontak, degil, dan mengganggu, yang akan menyebabkan masalah sosial dalam berinteraksi dengan sekitaran mereka².

Tingkah laku agresif pelajar di sekolah telah menjadi masalah universal, dan baru-baru ini cenderung meningkat. Berita mengenai pelajar yang terlibat dalam pelbagai bentuk rusuhan, perkelahian, pergaduhan, dan tindakan agresivitas lain semakin banyak didengar. Tingkah laku agresif pelajar di sekolah sangat pelbagai dan kompleks. Masalah tingkah laku agresif pelajar semakin rumit apabila tingkah laku agresif baru-baru ini ditunjukkan berperang di antara pelajar, saling memarahi, menghina dan mengejek individu dan kumpulan dan sebagainya.

Tingkah laku agresif yang berlaku di sekitaran pendidikan jika tidak ditangani dengan segera, selain mengganggu proses pembelajaran, juga akan menyebabkan pelajar cenderung untuk menyesuaikan diri dengan tabiat buruk ini. Situasi ini akan membentuk pelajar untuk meniru dan bersikap agresif juga, sehingga tingkah laku agresif pelajar di sekolah dianggap normal dan akan lebih meluas.

Sekolah, harus menjadi tempat yang menyenangkan, tempat yang selamat dan sehat, tempat di mana pelajar dapat mengembangkan pelbagai potensi mereka sepenuhnya. Sebaliknya, ketika mereka memasuki sekitaran sekolah, ternyata pelajar tidak selalu menyenangkan, mungkin sebaliknya malah membuat mereka tertekan, cemas dan takut. Imej agresivitas ketika memasuki sekitaran sekolah sering menghantui

1 Hurlock, Elizabeth B. Psikologi Perkembangan: Suatu Pendekatan Sepanjang Rentang Kehidupan. (Jakarta : Erlangga, 2011).

2 Abidin, Yunus. Desain Sistem Pembelajaran dalam Konteks Kurikulum 2013. (Bandung: PT Refika Aditama, 2014).

296 JURNAL LISAN AL-HAL 
pelajar.

Menurut Todd, Joana, et al. agresivitas dalam bentuk fisikal dan verbal di kalangan pelajar telah menjadi masalah serius yang wujud di pelbagai negara di seluruh dunia. Tingkah laku agresif pelajar telah memberi kesan negatif, baik kepada pelajar itu sendiri dan untuk orang lain. Anak-anak yang mengalami agresivitas akan mengalami masalah di masa depan, baik dari segi kesehatan dan kehidupan.

Mengenai tingkah laku agresif pelajar di sekolah, Wilson, et al. (2003) menyatakan: "Tingkah laku ini, walaupun tidak terlalu agresif, dapat menghalang pembelajaran dan menimbulkan masalah interpersonal bagi mereka yang terlibat". Selanjutnya, memetik pendapat Goldstein, Harootunian, \& Conoley, (1994), Wilson, et al. (2003) menyatakan: "Di samping itu, bentuk-bentuk tingkah laku agresif kecil dapat meningkat, dan sekolah-sekolah yang tidak dapat mengatasi perkembangan ini secara efektif dapat mewujudkan lingkungan di mana kekerasan dapat diterima secara normatif". Sekiranya tingkah laku agresif yang berlaku di sekitaran sekolah tidak ditangani dengan segera, selain mengganggu proses pembelajaran, ia juga akan menyebabkan pelajar cenderung untuk menyesuaikan diri dengan tabiat buruk ini. Semakin kerap pelajar terdedah kepada tingkah laku agresif, pelajar yang lebih biasa akan menghadapi situasi buruk ini, semakin tinggi kemampuan pelajar untuk menyesuaikan diri dengan tingkah laku agresif, dan persepsi pelajar bahawa tindakan agresif adalah biasa-biasa saja akan berkembang, terutamanya jika keadaan ini diperkuat oleh tingkah laku sebilangan guru yang juga cenderung bersikap agresif ketika berhadapan dengan pelajarnya. Situasi ini akan membentuk pelajar untuk meniru dan bersikap agresif juga, sehingga tingkah laku agresif pelajar di sekolah dianggap normal dan akan lebih meluas.

Agresif dikatakan sebagai kesalahan perilaku dan dapat memberi kesan terhadap perkembangan peribadi pelajar, oleh karna itu pihak sekolah melalui bimbingan dan Konseling diharapkan dapat membantu mengatasi tingkah laku ini. Kerana ini dianggap memberi kesan terhadap pencapaian pelajar, kedua-dua pelajar yang mempunyai tingkah laku agresif dan rakannya. Usaha memberi bantuan dapat diteruskan dengan memberikan layanan bimbingan dan Konseling, sesuai dengan pendapat Nursalim \& Suradi bahawa Bimbingan dan Konseling di sekolah mempunyai peranan yang sangat penting dalam membantu pelajar berkembang ke arah yang lebih optimum dan membantu mengatasi faktor-faktor yang menjadi penghalang kepada perkembangan pelajarpelajar ini. Dalam pelaksanaannya dalam ruang lingkup sekolah, salah satu 
perlayananan bimbingan dan Konseling yang sering dilakukan adalah perlayananan Konseling kelompok ${ }^{3}$.

Konseling kelompok sebagai bentuk Konseling dianggap mempunyai kelebihan berbanding dengan Konseling individu. Kelebihan ini termasuk kemampuannya untuk membantu menangani masalah yang timbul dengan lebih berkesan tanpa menjejaskan keberkesanannya. Bahagian yang efisien yang dimaksudkan ialah kemampuan Konseling kelompok untuk menjimatkan masa, wang, dan konselor dalam membantu dan mengatasi masalah pelajar yang sering timbul dalam kehidupan mereka.

Dalam perkembangannya, pelaksanaan Konseling kelompok dilihat lebih efektif apabila digabungkan dengan pendekatan terapi, penggunaan beberapa pendekatan untuk Konseling kelompok dapat mendorong keberkesanan prestasi Konseling, terutama dalam meredakan gangguan tingkah laku dan pemikiran pada siswa. Pendekatan yang relevan yang digunakan dalam pelaksanaan Konseling kelompok meliputi kognitif, tingkah laku, tingkah laku, dan emosional rasional. Penggunaan beberapa pendekatan ini dalam Konseling kelompok dapat membantu menyelesaikan masalah pelajar dengan lebih berkesan.

Konseling kelompok adalah bentuk Konseling yang berkesan dan efisien yang digunakan dalam populasi usia sekolah. Ini berdasarkan pendapat Vermon yang menyatakan bahawa Konseling kelompok adalah satu bentuk terapi yang berlaku untuk tetapan sekolah di mana proses Konseling dibatasi oleh masa ${ }^{4}$. Hakikat bahawa Konseling kumpulan pendek sangat penting terutama bagi pelajar yang memerlukan sesuatu untuk menolong mereka dengan segera, Konseling kelompok mengajar pelajar bagaimana berfikir dengan lebih baik, pelajar bukan sahaja merasa lebih baik tetapi akan menjadi lebih baik, kerana pelajar membetulkan kesalahan berfikir yang menyebabkan masalah untuk dia.

\section{B. Metode Penelitian}

Penelitian ini menggunakan pendekatan kuantitatif quasi experimental research. Menurut Arikunto ${ }^{5}$ dan Marliani penelitian eksperimen adalah sebuah penelitian untuk membangkitkan timbulnya

3 Nursalim, M. dan Suradi. Layanan Bimbingan dan Konseling. (Jakarta: Unesa University Press, 2002).

${ }^{4}$ Erford, B.T. Professional School Counseling: A Handbook of Theories, Programs \& Practices. (Austin, Texas: CAPS Press, 2004).

${ }^{5}$ Arikunto, Suharaimi. Prosedur Penelitian: Suatu Pendekatan Praktek. (Jakarta : PT. Rineka Cipta, 2013).

298 JURNAL LISAN AL-HAL 
suatu keadaan atau kejadian yang dilakukan dengan maksud untuk melihat suatu akibat atau treatment. Penelitian dengan jenis ini bertujuan untuk mengungkapkan hubungan sebab-akibat dengan cara melibatkan kelompok kontrol disamping kelompok eksperimen, namun pemilihan kedua kelompok tersebut tidak dilakukan dengan teknik random.

Peneliti menggunakan desain eksperimen seri (equivalent time samples design), yaitu desain eksperimen yang dilakukan berdasarkan satu seri pengukuran variabel terikat terhadap suatu kelompok subyek.

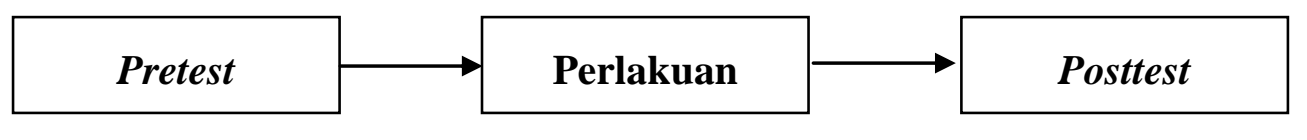

$\mathrm{T} 1$

$\mathrm{X}$

$\mathrm{T} 2$

Gambar 1. Desain Pretest Posttest

Keterangan :

$\mathrm{T} 1$ : pretest (tes awal) $\mathrm{T} 2$ : posttest (tes akhir) $\mathrm{X}$ : treatment (perlakuan)

Penggunaan jenis eksperimen ini dianggap peneliti paling tepat karena hanya beberapa siswa saja yang tercatat melakukan tindak agresivitas di sekolah dan juga lebih efisien dalam hal waktu, sebab sampel penelitian tidak memungkinkan untuk mencampurnya dengan tingkatan kelas lainnya, dikhawatirkan akan mengganggu pada proses pemberian konseling kelompok yang berlangsung.

\section{Hasil Peneltian}

Subjek penelitian berjumlah 10 anak pada kelompok eksperimen yang diperoleh dari rekomendasi Guru BK SMP Negeri 13 Surabaya yang merupakan kelompok eksperimen. Berdasarkan hasil identifikasi peneliti di lokasi penelitian, subjek yang sesuai dengan kriteria yang akan diteliti berjumlah 10 orang kelompok eksperimen dan 10 anak pada kelompok kontrol. Sebelum subjek penelitian ditentukan, peneliti menggali data terlebih dahulu mengenai data siswa yang tercatat melakukan tindak agresivitas di sekolah dari pihak guru BK. Kemudian peneliti melakukan pretest untuk memastikan bahwa siswa yang ditunjuk oleh guru BK adalah siswa yang memiliki perilaku agresif di sekolah.

Berdasarkan data mengenai hasil skoring perilaku agresif di sekolah yang didapatkan baik sebelum dan sesudah perlakuan, menghasilkan data mean dari kelompok eksperimen seperti di bawah ini: 
Tabel 1

Paired Samples Statistics

Paired Samples Statistics

\begin{tabular}{|ll|c|r|c|c|}
\hline & Mean & Nilai & $\begin{array}{c}\text { Std. } \\
\text { Deviation }\end{array}$ & $\begin{array}{c}\text { Std. Error } \\
\text { Mean }\end{array}$ \\
\hline $\begin{array}{ll}\text { Pair } \\
\mathbf{1}\end{array}$ & $\begin{array}{l}\text { PreTest } \\
\text { PostTes } \\
\mathbf{t}\end{array}$ & 74.9000 & 10 & 13.62555 & 4.30878 \\
& 51.9000 & 10 & 11.28864 & 3.56978 \\
\hline
\end{tabular}

Tabel 2

Paired Samples Test

Paired Samples Test

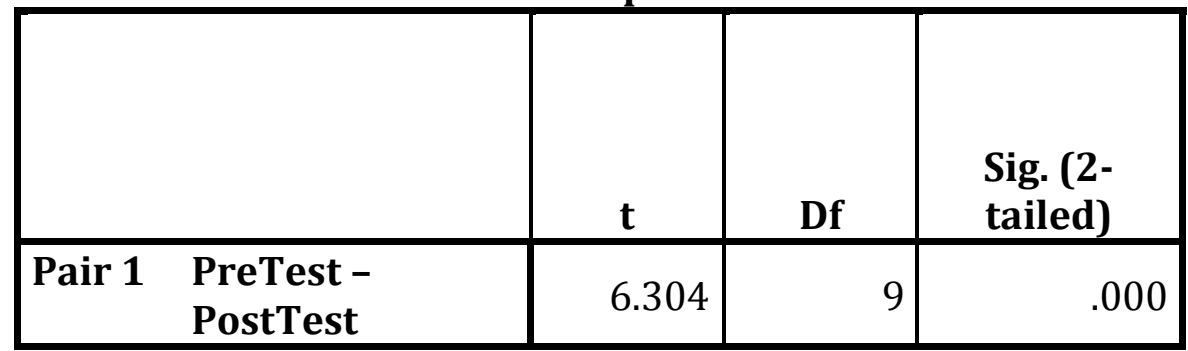

\section{Pembahasan}

Setelah dibandingkan antara nilai mean pada saat pre-test dan post test, terlihat penurunan nilai mean, nilai pada pre-test 74,900 dan nilai pada post-test 51,900, yang artinya terdapat penurunan tingkat agresivitas siswa di sekolah menengah pertama SMPN 13 Surabaya yang tercatat berperilaku agresif setelah diberikan layanan konseling kelompok.

Berdasarkan output di atas, diketahui bahwa nilai sig. (2-tailed) sebesar $0,000<(\mathrm{P} 0,005)$, maka dapat disimpulkan bahwa pemberian layanan konseling kelompok dapat menurunkan perilaku agresif siswa Sekolah Menengah Pertama Negeri 13 Surabaya.

Hasil analisis pengaruh layanan konseling terhadap penurunan perilaku agresif Siswa Sekolah Menengah Pertama adalah sebagai berikut:

300 JURNAL LISAN AL-HAL 
Tabel 3

Independent Sample T-Test (Group Statistics)

Group Statistics

\begin{tabular}{|l|l|r|r|r|c|}
\hline & Kelompok & \multicolumn{1}{|c|}{ Nilai } & \multicolumn{1}{c|}{ Mean } & \multicolumn{1}{c|}{$\begin{array}{c}\text { Std. } \\
\text { Deviation }\end{array}$} & $\begin{array}{c}\text { Std. Error } \\
\text { Mean }\end{array}$ \\
\hline Pre_Test & Kontrol \\
& $\begin{array}{l}\text { Eksperime } \\
\text { n }\end{array}$ & 10 & 81.2000 & 19.03097 & 6.01812 \\
\hline $\begin{array}{l}\text { Post_Tes } \\
\text { Kontrol }\end{array}$ & 10 & 74.9000 & 13.62555 & 4.30878 \\
\hline & $\begin{array}{l}\text { Eksperime } \\
\text { n }\end{array}$ & 10 & 82.6000 & 19.14970 & 6.05567 \\
\hline
\end{tabular}

Tabel 4

Independent Sample T-Test

Independent Samples Test

\begin{tabular}{|c|c|c|c|c|c|}
\hline & \multicolumn{2}{|c|}{$\begin{array}{l}\text { Levene's Test for } \\
\text { Equality of } \\
\text { Variances } \\
\end{array}$} & \multicolumn{2}{|c|}{$\begin{array}{c}\text { t-test for } \\
\text { Equality of } \\
\text { Means } \\
\end{array}$} \\
\hline & & $\mathbf{F}$ & Sig. & $\mathbf{t}$ & Df \\
\hline Pre_Test & $\begin{array}{l}\text { Equal variances } \\
\text { assumed } \\
\text { Equal variances not } \\
\text { assumed }\end{array}$ & 4.090 & .058 & $\begin{array}{l}.851 \\
.851\end{array}$ & $\begin{array}{r}18 \\
16.30 \\
7 \\
\end{array}$ \\
\hline Post_Test & $\begin{array}{l}\text { Equal variances } \\
\text { assumed } \\
\text { Equal variances not } \\
\text { assumed }\end{array}$ & 8.937 & .008 & $\begin{array}{l}4.367 \\
4.367\end{array}$ & $\begin{array}{r}18 \\
14.58 \\
1\end{array}$ \\
\hline
\end{tabular}

Berdasarkan hasil analisis pengaruh layanan konseling kelompok terhadap penurunan perilaku agresif pada siswa sekolah menengah pertama, diperoleh nilai mean kelompok kontrol dan nilai mean kelompok eksperimen pasca pemberian layanan konseling kelompok sejumlah 82,6000 dan 51,9000, dengan $p$ value pasca perlakuan $0,008<(\mathrm{P} 0,05)$ yang artinya terdapat perbedaan yang signifikan pengaruh pemberian layanan konseling kelompok terhadap penurunan perilaku agresif siswa sekolah menengah pertama. 


\section{E. Simpulan}

Berdasarkan hasil penelitian mengenai pengaruh penerapan konseling kelompok terhadap penurunan agresivitas siswa Sekolah Menegah Pertama, dapat disimpulkan hal-hal sebagai berikut: Pertama, Penerapan layanan konseling kelompok terbukti memiliki pengaruh dalam menurunkan tingkat agresivitas siswa Sekolah Menengah Pertama Negeri 13 Surabaya dan Kedua, Terdapat perbedaan pengaruh penerapan konseling kelompok terhadap penurunan agresivitas siswa Sekolah Menegah Pertama pasca pemberian layanan konseling kelompok.

\section{DAFTAR PUSTAKA}

Abidin, Yunus. Desain Sistem Pembelajaran dalam Konteks Kurikulum 2013. Bandung: PT Refika Aditama, 2014.

Anantasari. Menyikapi Perilaku Agresif Anak. Yogyakarta : Kanisius, 2006.

Arikunto, Suharaimi. Prosedur Penelitian: Suatu Pendekatan Praktek. Jakarta : PT. Rineka Cipta, 2013.

Erford, B.T. Professional School Counseling: A Handbook of Theories, Programs \& Practices. Austin, Texas: CAPS Press, 2004.

Hurlock, Elizabeth B. Psikologi Perkembangan: Suatu Pendekatan Sepanjang Rentang Kehidupan. Jakarta : Erlangga, 2011.

Marliani, Rosleny. Psikologi Eksperimen. Bandung: Pustaka Setia, 2013.

Nursalim, M. dan Suradi. Layanan Bimbingan dan Konseling. Jakarta: Unesa University Press, 2002.

Prayitno. Layanan Bimbingan Kelompok Dan Konseling Kelompok. Padang: Universitas Negeri Padang, 2004.

Rumini, Sri dan Siti Sundari. Perkembangan Anak dan Remaja. Jakarta: PT. Rineka Cipta, 2004.

Sukardi. Metodologi Penelitian Pendidikan Kompetensi dan Praktiknya. Jakarta : Bumi Aksara, 2013.

Wibowo, Mungin Eddy. Konseling Kelompok dan Perkembangan. Semarang: UPT Universitas Negeri Semarang, 2005. 